\title{
Worlding Cinema
}

\author{
Christine Gledhill \\ Visiting Professor of Cinema Studies, School of Media and Communication, \\ University of Leeds, Leeds, United Kingdom \\ christine.gledhill@gmail.com
}

\begin{abstract}
Against the narrowly commercial and homogenising term 'world cinema' that lumps together a diversity of 'foreign' films as a category, the notion of 'the local' relativizes the idea of the 'national' as a singular entity. It suggests the pivoting around each other of 'there' and 'here,' thereby avoiding precisely fixed locations and calling on the dynamism of their relationship. The local, captures not only particular geo-political locations but historical relationships, which, interacting with changing conditions, produce the shifting frameworks of thinking, feeling, experience, and aesthetic perception that shape local practices, traditions, and cultural forms. However, this specificity is often called on to endorse an authenticity uncontaminated by metropolitan sophistication or global uniformity, enabling local products to travel to an elsewhere beyond national boundaries. The value of 'world' over 'global' lies in its call on the space shared by many different nationals, whereas 'global' suggests the homogenisation enforced by multi-national corporate and neo-colonial Western powers. As an alternative concept, 'trans-national' applied to cinema has the virtue of acknowledging the existence of nationally defined geo-historical and cultural differences as well as the reality of cross-border migration of personnel, technologies, and films, along with the complexity of international co-production. However, if the term keeps the idea of the 'national' in place, the boundaries it marks are neither natural nor fixed. If local film genres and narrative forms function as public sites in which aesthetic histories, cultural frames of reference and social experiences feed and negotiate with each other, the question arises how far the trans-national intensification of this activity now produces a new space for an emergent 'world imaginary': the idea of a shared 'world'.
\end{abstract}




\section{Keywords}

world cinema - local - global - transnational - Hollywood

Prompted by the question, 'what is world music?' the presenter of ввс Radio's Late Junction quoted, 'it's local music, but not from here.' This neat formulation, pinpoints both the problems and potential of the adjectival use of 'world.' Against the narrowly commercial and homogenising term 'world cinema' that lumps together a diversity of 'foreign' films as a category for DVD shelving, TV schedules and festivals, it suggests the pivoting around each other of 'there' and 'here,' thereby avoiding precisely fixed locations and calling on the dynamism of their relationship.

The value of 'world' over 'global' lies in its call on the space shared by many different nationals, whereas 'global' suggests the homogenisation enforced by multi-national corporate and neo-colonial Western powers. As an alternative, 'trans-national' applied to cinema has the virtue of acknowledging the existence of nationally defined geo-historical and cultural differences as well as the reality of cross-border migration of personnel, technologies and films, along with the complexity of international co-production. However, if the term keeps the idea of the 'national' in place, the boundaries it marks are neither natural nor fixed. The populations gathered within named geo-political spaces share no singular identity but comprise diverse and competing communities and classes, both indigenous and newly migrant. The notion of 'the local' thus relativizes the idea of the 'national' as an homogenous entity, which is in fact made up of many locals, themselves in a 'here-and-there' relationship with their national centres, as well as with each other. The many cinemas of India, for example, with its over 70 languages and different religions, exist in tension with the dominance of the Hindi Bombay industry.

The local, designates not only shifting geo-political locations but historical relationships, which in interaction with changing conditions produce the frameworks of thinking, feeling, experience, and aesthetic perception that shape specific local practices, traditions and cultural forms. This specificity is often called on to endorse an authenticity uncontaminated by metropolitan sophistication or global uniformity, enabling local products to travel to an elsewhere beyond state boundaries along routes of trade, tourism, and cultural exchange, often taken as representing 'national' identities. Such value, however, can be double-edged in its use by festival circuits, film centre programmes, academic conferences and the publishing industry to separate national cinemas into discrete conceptual boxes, defined by unique characteristics that are then thought threatened by infiltration of alien elements, 
imitated or copied from, or imposed by, economically and culturally dominant centres. Moreover, as Paul Willemen (1994) pointed out, a focus on the national risks political confusion with 'nationalism,' to whose interests the national is often co-opted as a means of maintaining geo-political boundaries. In this sense, local cultural specificity includes struggles for and with the national and nationalism. James Donald (1992) goes further, arguing that it is culture that produces the national, rather than the other way round. But if local communities are historically and culturally located, they are not (unless by force) hermetically sealed off from each other. If culture insists that films come from somewhere, they are also on the move, going somewhere. And so, indeed, is 'the local,' which may not reside within, but across national borders, creating trans-nationally localized communities. Kobena Mercer 1988, invoking the mantra 'think local, act global,' suggests that the success of Hanif Kureshi's My Beautiful Launderette (1985, Stephen Frears) lay less with its British box-office than its appeal to a new trans-national gay audience. Similarly, feminist film festivals draw women filmmakers and audiences across national and ethnic boundaries.

However, specific differences-'not from here' - create value, contributing to cultural travel as sources both of difference and innovation. Till recently, the multivalent histories of such travel have been obscured by the assumption of one-way traffic from the West-in terms of cinema meaning largely, Hollywood - to the rest of the world. This model of uni-directional travel from centre to periphery threatening the discrete identity of national cinemas is challenged by empirical and historical evidence and for its limited conception of the processes of cultural production, circulation and influence. How far, for example, is it known in Western film studies that from the 1950s to the 1980s, the Turkish Yeşilçam cinema constituted, after Hollywood and Bombay cinemas, the world's third largest film industry, operating in a quite different sphere of circulation (2011)? From earliest times, traders in cultural goods have criss-crossed geo-political boundaries, leading to interchanges of technologies, techniques and artefacts in processes of cultural appropriation, exchange, cross-fertilization and commercial exploitation. Some years ago the Venetian exhibition, Venezia e L'Islam: 828-1797, arranging side-by-side Islamic and Christian artworks and domestic objects, recorded how even during the height of the Crusades trading between Venice and Asia Minor continued the exchange of artefacts, technologies, materials, techniques, and artistic styles. Take any cultural phenomenon - opera, gothic horror, melodrama, folk stories (e.g. the travels of the Ramayana between India and Indonesia) — and we find a history of intertwined aesthetic, commercial, and economic exchanges through the movements of personnel, companies and artefacts between different countries. 
The arrival of photography and cinematography speeded up this process exponentially. Cinema emerged at the apex of developing technologies of travel, industrial production, and a field of mass entertainment and news generation growing throughout the nineteenth century, which via colonisation, wars, revolutions or internal social reforms were driving processes of modernisation in different ways across the world. Following the routes of circulation already set up by travelling theatrical troupes, translated print fictions, newspaper serialisations, photographic images, cinema proved also capable of absorbing any local cultural material their producers found to hand, forming the basis for documentaries, travelogues and film fictions. Films functioned as records of, or catalysts for, modernisation taking place at different rates and in different ways in different parts of the world, bringing countries into each other's view. For some enthusiasts this raised the hope of generating mutual international understanding, hopes soon counteracted by fears of Hollywood's power to Americanise the world.

For a uni-directional centre-periphery model, this is the most contested of trans-national contacts. Unless refused import permission, most national film cultures involve cinematic experience and concomitant expectations that include Hollywood's genres. While recognizing the American film industry's aggressive enforcement of its economic power, Miriam Hansen (2000a) argues that the conditions of its emergence-both as economic powerhouse and as a nation-building cinema founded on the participation and adherence of large immigrant communities - led to the forging of a cinematic aesthetic attuned to the bodily and subjective experience of urbanisation, industrialisation and new forms of work and public life. In particular, Hansen suggests, it was Hollywood's proliferation of unruly, body-impacting genres - adventure serials, thrillers, melodramas, weepies, horror films - catching up in different ways the contrary sensations of disorientation and spectacle, anxiety and hope, bodily exhaustion and hyper-stimulus of modernity that made its films capable of travel across national boundaries and subsequent transformation within local film industries. In its role as mass-mediator of modernity, American cinema, Hansen suggests, succeeded because it challenged locally entrenched hierarchies and traditions (200ob). Representing a form of 'vernacular modernism,' it produced the world's 'first global vernacular.' However, this does not mean unmediated replication of either Hollywood's generic or narrative forms as they are absorbed into local modes of storytelling and social recognition, as is shown by Yeşilçam cinema's irreverant remaking of its genres or Irish filmmakers' use of its familar generic tropes to question the problematic relations of Ireland to an Americanized modernity and British colonialism.

Despite American cinema's advantage at the forefront of cinematic technology and development of a star and genre system embedding populist tropes 
of modern democratisation, it is fast becoming clear that the circulation of cinemas across borders has been far from one-way. For geographic and cultural boundaries function not only as demarcations but as crossing points, places of encounter, trade, fascination, power struggle and exchange. The travels of film technologies, genres and styles form a rhizomatic web of cultural exchange, criss-crossing between regions and countries, much like flight magazine maps of airplanes criss-crossing the world. Thus, for example, the aesthetic of wenyi is interchanged between Japan and China, combining the nostalgia of romantic loss with fascination for the 'foreign' (Yeh 2013, Zhang 2018); expressionist performance and cinematography between Germany and India (Bhaskar 2018); martial arts between China, Hong Kong and Hollywood (Rodriguez-Ortega 2012); Latin musical and dance forms between Cuba and Mexico (Monsiváis 2018). In this sense, 'there' is already 'here': the local is effectively home to the 'trans-national.'

How to track and conceptualise such encounters is explored in different ways by contributors to an anthology I recently co-edited with Linda Williams, Melodrama Unbound (2018), one aim of which was to investigate the pertinence of the Western term 'melodrama' for theatrical and cinematic forms grounded in other performance traditions. Zhen Zhang, on Chinese cinema of the 1920s, uses the term 'synergy' to describe the cross-fertilisation between the romantic modality of wenyi, the figure of the orphan as universal trope of social deracination, and Chinese enthusiasm for the films of D.W. Griffith (83-97). Writing about Mexican 'Golden Age' melodrama of the 1940s and 195os, Carlos Monsiváis focuses on the 'contact zone' between an historically ingrained Catholicism, the culture of cabaret with its Cuban connections, and Hollywood melodramas (151-167). Ira Bhaskar draws on the convergence of the performance practices bhava and those of German expressionism to explain Indian cinema's emotional melodramas of modernisation in films of the $1930 \mathrm{os}$ and $1940 \mathrm{os}\left(253^{-272}\right)$. Far from the pejorative associations of 'adaptation,' 'imitation,' or 'copy,' such trans-cultural encounters, Zhang suggests, 're-energize regionally grown forms' (88).

These accounts focus the nature of media arts as practices of aesthetic perception and social experience, feeding each other to form the imaginaries of different cultures. Useful in this respect, is Mikhail Bakhtin's contention that, because they arise out of historical social uses, all communications, whether social or artistic, use generic forms (1986). Literary and artistic practices recast the generic figures of social communication into new creative forms with different aesthetic and imaginary purposes. In terms of specific film genres, Steve Neale (1995) makes the useful distinction between codes of generic verisimilitude (enabling recognition of different fictional worlds) and 
codes of cultural verisimilitude (those that represent what a society takes its 'reality' to be), while also emphasising the processes of circulation between media genres and socio-cultural discourses. In this respect claims on realism attempt to change the terms of cultural and generic verisimilitude by which reality is understood and constructed, thereby challenging and expanding the boundaries of perception and representation. I have suggested elsewhere that the 'national,' as a set of geo-historical cultural conventions, is similarly generic (2007). However, postmodern globalisation of markets and international co-production deals, combined with expansion of new media, have vastly speeded up the centrifugal dispersal of national, cultural and narrative figures, which increasingly spin off from their original cultural grounding to become part of a trans-national pool of generic markers. If generic forms from 'there' hark back to the 'local' pasts out of which they were generated, their re-articulation in the present of a 'foreign here' encounters not only different regimes of cultural verisimilitude — of social recognition — but a range of indigenous cultural traditions and practices, both historical and contemporary, with which they must negotiate.

However, in such pivoting of here and there, the grounding of cultural criticism is undercut, challenging the authority of critic and analyst over interpretation, meaning and value. If we cannot all locate ourselves inside each other's cultures, nor do we want to remain cultural tourists celebrating examples of exoticised difference. Bakhtin, when asked his view of the possibilities of comparative literature, argued the productive role of critical 'outsideness': 'A meaning only reveals its depths once it has encountered and come into contact with another, foreign meaning; we seek answers to our own question in it; and the foreign culture responds to us by revealing to us its new aspects and new semantic depths' (1986: 7). Bakhtin, thus, conceives the critical encounter between here and there as a dialogic process on several levels. For any communicative form carries the meanings of its past uses, themselves generated out of specific social needs. To make such uses 'our own' requires negotiation with both past 'others' and the anticipated understandings of those we now address. Meanings are therefore not fixed but dynamically produced in the moment of encounter. This is as true for makers and audiences as for critics. Savaş Arslan (2011) draws on the Turkish concept özenti to suggest the alterity of elsewhere, when going out to meet the 'foreign' entails never returning home the same. Making the pivot in the opposite direction, Colin Burnett (2013), drawing on cultural art historian Michael Baxandall, argues the active role of interpretation by filmmakers who re-read and remake foreign influences to their own ends. Against demands for preservation of local identities, uncontaminated by 'foreign' contacts, counter-arguments thus emphasise the 're-tooling' or 
're-accenting' under local conditions of practices and tropes imported or borrowed from 'there.'

This changes the nature of cultural criticism. If asking questions a foreign culture has not asked itself means there is neither a fixed authenticity to be captured nor definitive meaning to be explained, neither should we expect answers that replicate the perspectives of the different culture and time from which our questions arise. For posing the questions the work did not, or could not, ask stirs within it - makes visible — new dimensions that reveal the stakes of its own history and its latent potential. Thus, the work's revelation of its 'new semantic depths' may open new perspectives on the history that underpins our questions. In such contacts, then, neither side denies its socio-historical locatedness, for this is always present in the cultural forms it uses, carrying the internalised structures of past users into present encounters with externalised 'others.' For Bakhtin, then, the 'outsideness' of critique is not simply a restriction but involves 'creative understanding.' Neither 'here' nor 'there' remain untouched as our questions come back to us newly inflected and the work reveals its new possibilities. Thus contacts between 'here' and 'there' open up new insights out of the dialogic encounter. Such creative-critical dialogue is always in process, affording temporary footholds only, while continually unfolding new pathways to understanding that engage not only cultural meanings but newly forming imaginary and affective cultural territory.

Finally, Savaş Arslan's inauguration of Studies in World Cinema suggests a new critical possibility and a new question. If local film genres and narrative forms function as public sites in which aesthetic histories, cultural frames of reference and social experience feed and negotiate with each other, the question arises how far the trans-national intensification of this activity now produces a new space for an emergent 'world imaginary': the idea of a shared 'world'-materialised not only by boundary-crossing media but by cross-national movements such as médecins-sans-frontières or journalists-without-borders, climate emergency strikes, campaigning organisations such as Amnesty International, Extinction Rebellion and Avaaz. In bringing trans-national exchanges between the cinemas of the world into focus, Studies in World Cinema contributes to the critical and institutional infrastructure that makes an emerging, if contested, awareness of world connectednss possible.

\section{References}

Arslan, Savaş. 2011. Cinema in Turkey: A New Critical History. Oxford: Oxford University Press. 
Bakhtin, Mikhail M. 1986. [1970]. 'Response to a Question from the Novy Mir Editorial Staff.' In Caryl Emerson and Michael Holquist (eds.), Speech Genres and Other Late Essays. Trans. Vern W. McGee. 1-9. Austin, Texas: University of Texas Press.

Bhaskar, Ira. 2018. 'Expressionist Aurality: The Stylized Aesthetic of Bhava in Indian Melodrama.' In Gledhill and Williams (eds.), Melodrama Unbound. 253-272. New York: Columbia University Press.

Burnett, Colin. 2013. 'Transnational Auteurism and the Cultural Dynamics of Influence: Mani Kaul's “Non-Representational' Cinema.' Transnational Cinemas, vol. 4 no. 1: $3^{-24}$.

Donald, James. 1992. 'How English Is It?' In Sentimental Education: Schooling, Popular Culture and the Regulation of Liberty. London: Verso.

Gledhill, Christine. 2007. 'Genre and Nation.' In Brian Mcllroy (ed.), Genre and Cinema: Ireland and Transnationalism. 11-25. Abingdon, Oxon: Routledge.

Gledhill, Christine and Linda Williams (eds). 2018. Melodrama Unbound. New York: Columbia University Press.

Hansen, Miriam. (2000a). 'Mass Production of the Senses: Classical Cinema as Vernacular Modernism.' In Gledhill and Williams (eds.), Reinventing Film Studies. 316-331. London: Arnold.

Hansen, Miriam. 20oob. 'Fallen Women, Rising Stars, New Horizons: Shanghai Silent Cinema as Vernacular Modernism.' Film Quarterly, vol. 54 no. 1: 10-22.

Mercer, Kobena. 1988. 'Think Local, Act Global.' In Black Film, British Cinema. ICA Documents no. 7 .

Monsiváis, Carlos. 2018. 'One Suffers but One Learns: Melodrama and the Rules of Lack of Limits.' In Gledhill and Williams (eds.), Melodrama Unbound. 151-183. New York: Columbia University Press.

Neale, Steve. 1995. 'Questions of Genre.' In Barry Keith Grant (ed.), Film Genre Reader II. 16o-184. Austin: University of Texas Press.

Rodriguez-Ortega, Vicente. 2012. 'Homoeroticism Contained: Gender and Sexual Translation in John Woo's Migration.' In Christine Gledhill (ed.), Gender Meets Genre in Postwar Cinemas. 191-202. Urbana: University of Illinois Press.

Willemen, Paul. 1994. 'The National.' In Looks and Frictions: Essays in Cultural Studies and Film Theory. London: BFI.

Yeh, Emilie Yueh-yu. 2013. 'A Small History of Wenyi.' In Carlos Rojas and Eileen ChengYin Chow (eds.), The Oxford Handbook of Chinese Cinemas. 224-249. Oxford: Oxford University Press.

Zhang, Zhen. 2018. 'Transnational Melodrama, Wenyi, and the Orphan Imagination.' In Gledhill and Williams (eds.), Melodrama Unbound. 83-95. New York: Columbia University Press. 